\title{
Study of shrimp drying
}

Ph. D. Alexandr E. Suslov, sergs53@mail.ru

D. Sc. Yuriy A. Fatykhov, yuriy.fatyhov@klgtu.ru

Kaliningrad State Technical University

1, Sovetsky ave., Kaliningrad, 236022, Russia

The purpose of the research was to determine the energy-saving operating parameters of the shrimp drying for the production of snack products. Analysis of the energy intensity of the process and the conditions for achieving product quality showed that convective drying the most appropriate technique for obtaining snack products from boiled shrimp. The method of experiments for convective drying of raw materials is developed. As a result of research data on kinetics of drying cleared boiled sea shrimp and boiled sea shrimp in a shell without head depending on various parameters of process are received. In the process of convective drying temperature and humidity of the working environment of the drying chamber are the most influencing factors. Their relationship with the rate of dehydration of sea shrimp in the form of a second order polynomial is obtained by the method of experiment planning. Based on the results of the study, mathematical models of the drying process of purified boiled sea shrimp and boiled sea shrimp in a shell without head in a convective drying plant were developed. Regression equations describing the effect of the regime parameters of convective drying on the rate of dehydration of the product were obtained. A mathematical model of the process of convective drying boiled meat of sea shrimp and shrimp in the shell without head, establishing the relationship of the process parameters: humidity $\varphi$, and temperature $T$ of the working medium of the convective drying unit at the rate of dehydration of the product was developed. The rational parameters of convective drying the meat of sea shrimp and shrimp in the shell without head are $\varphi=80 \%$ and $T=100^{\circ} \mathrm{C}$.

Keywords: convective drying; sea shrimp; snack products; energy saving parameters; rate of dehydration. DOI: $10.17586 / 2310-1164-2019-12-2-60-68$

УДК 664.959

\section{Результаты исследования процесса сушки креветки}

\author{
Канд. техн. наук А.Э. Суслов, serg53@mail.ru \\ д-р техн. наук Ю.А. Фатыхов, yuriy.fatyhov@klgtu.ru \\ Калининградский государственный технический университет \\ 236022, Россия, Калининград, Советский пр., 1
}

Определяли энергосберегающие режимные параметры процесса сушки креветки для производства снековой продукции. Анализ энергоемкости процесса, условий достижения качества продукции показал, что наиболее целесообразной для этой цели является конвективная сушка. Разработана методика проведения опытов для конвективной сушки сырья. Получены данные по кинетике сушки очищенной вареной морской креветки и вареной морской креветки в панцире без головы в зависимости от различных параметров процесса: температура рабочей среды $-80 ; 90 ; 100^{\circ} \mathrm{C} ; \varphi-$ влажность рабочей среды (воздуха) - 30; 55; 80\%. В процессе конвективной сушки влияющими факторами являются температура и влажность рабочей среды сушильной камеры. Методом планирования эксперимента получена их взаимосвязь с темпом обезвоживания морской креветки в виде полинома второго порядка. На основании полученных результатов исследования разработаны математические модели процесса сушки очищенной вареной морской креветки и вареной морской креветки в панцире без головы в конвективной сушильной установке. Получены уравнения регрессии, описывающее влияние режимных параметров конвективной сушки на темп обезвоживания продукта. Разработана математическая модель процесса конвективной сушки вареного мяса морской креветки и креветки в панцире без головы, устанавливающая взаимосвязь параметров процесса: влажности ф и температуры $T$ рабочей среды конвективной сушильной установки на темп обезвоживания продукта. Установлены рациональные параметры процесса конвективной сушки мяса морской креветки и креветки в панцире без головы $\varphi=80 \%, T=100^{\circ} \mathrm{C}$.

Ключевые слова: конвективная сушка; морская креветка; снековая продукция; энергосберегающие параметры; скорость обезвоживания. 


\section{Introduction}

Drying is one of the ways of food preservation, including hydrobionts $[1,2]$. Due to rising energy prices, there is a question of creating energy-saving and highly efficient technologies for drying food products [3, 4].

In the total volume of production of hydrobionts, a special place is occupied by the fishery of invertebrates, primarily crustaceans. More than 100 species of shrimp are of commercial importance [1]. High taste qualities and nutritional value of shrimp determine great interest in them on the world market. One of the ways to expand the range of products based on the use of shrimp meat is the production of snack products. In snack technology, the most important and energy-consuming process is the drying of shrimp meat.

The analysis of various methods of drying of the Chinese shrimp is given [5]. The paper [6] analyzes the effect of drying temperature on the physico-chemical and microstructural properties of shrimp meat. In $[7,8]$ the advantages of the method of convective drying are substantiated and the parameters of moisture transfer during the drying of shrimp are determined. However, these parameters were estimated using the analytical model of Dinser and Dost [8] without comparison with experimental data with energy-saving aspect.

The purpose of this research was to determine the energy-saving regime parameters of the process of drying shrimp for the production of snack products. The analysis of energy intensity of process, conditions of achievement of quality of production [2, 3 ] showed that the most expedient for receiving snack production from boiled shrimp is convective drying.

\section{Description of the experimental setup and methodology the experiments}

The schematic diagram of the experimental drying plant for convective drying is shown in fig.1.

The installation works as follows. Thawed shrimp is spread evenly on metal pallets. Pallets are installed in the working chamber. A thermosonde is installed in the shrimp. To create the required temperature, the electric air heater (4) is switched on. To maintain the desired humidity of the working environment, steam from the steam generator (6) is supplied to the drying chamber (2) by means of a humidifier (5). A constant drying speed is maintained by a fan (1). During the drying process, the moisture from the product evaporates and condenses on the surface of the air cooler (3) and flows into the catchment. After entering the drying mode, the temperature and humidity of the air in the unit are maintained automatically and can be changed if necessary by monitoring and control devices.

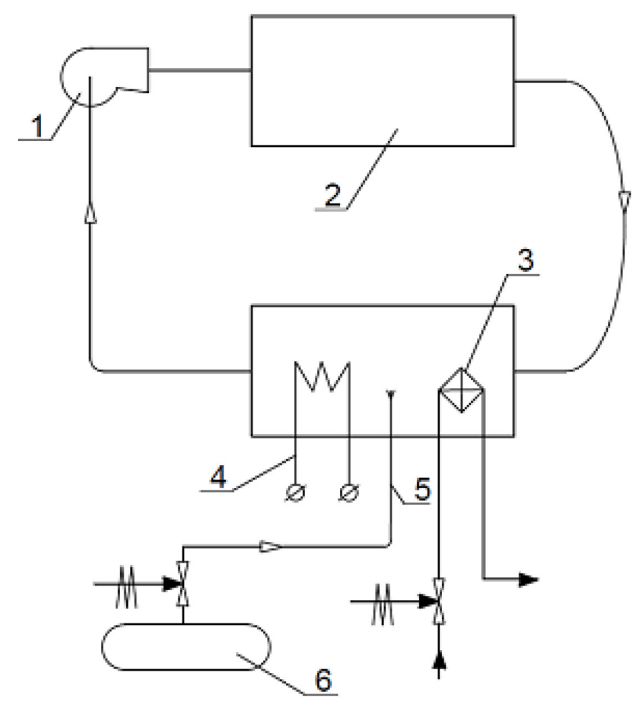

Figure 1. Schematic diagram of the experimental drying plant:

1-fan; 2 -drying chamber; 3 -air cooler; 4 -electric air heater; 5 - humidifier; 6 -steam generator

As object of research was selected as the sea boiled shrimp in the shell without the head, cooked and peeled sea shrimp. On the basis of the paper [2] the final moisture content of the finished product, which is $27-30 \%$, is accepted.

Before downloading the shrimp to the setting determined by the initial humidity of the product $[5,6]$. A resistance thermometer was used to measure the temperature in the center of the shrimp. After entering the mode (set temperature and humidity in the drying chamber), the temperature in the center of the shrimp was fixed every 15 minutes. Based on the paper [1, 3, 9-13], the optimal air velocity in the chamber was taken, which was $-1.3 \mathrm{~m} / \mathrm{sec}$. 
During the drying process, the chamber was opened at certain intervals and the material was taken to determine the intermediate humidity of the shrimp, at the end of the drying process the final moisture of the product was determined $[7,8]$.

The study of the kinetics of dehydration of hydrobionts depending on the method of cutting raw materials, the type of drying plants used and the operating parameters of the drying process made it possible to choose the most rational conditions for the process [10, 11].

Planning of the experiment and processing of experimental data were carried out by known mathematical methods $[12,13]$.

\section{Research result}

A complex of studies of the process of convective drying of boiled sea shrimp in the shell without a head and purified boiled sea shrimp on the experimental setup. During the drying process, the shrimp controlled the temperature and humidity of the working environment (air) in the drying chamber, the temperature in the center of the shrimp.

Control of parameters $\left(T-\right.$ temperature of the working medium $-80 ; 90 ; 100^{\circ} \mathrm{C} ; \varphi$ - humidity of the working medium (air) - 30; 55; 80\%) allowed to determine experimentally the most appropriate parameters of convective drying, as well as to study the kinetics of the process. According to the results of the experiments at different modes, drying curves were obtained, the processing of which allowed to optimize the dehydration modes while maintaining high quality indicators of dried shrimp.

In figures 2, 3, 4, 5 presents the thermograms and drying curves of cooked marine prawns, built according to the experimental data for different values of fluid temperature dryer at a humidity of $80 \%$. To construct the drying curves, both the initial and final moisture values of the product were taken as the basis for the calculation, this allowed to distribute the experimental error over the entire length of the drying curve, reducing the error in further processing [3, 11]. In addition, periodic sampling was carried out to determine the current moisture content of the test product.

According to the presented graphs (fig. 2, 3,6) for marine shrimp boiled and purified according to the graphs (fig. 4, 5, 7) for sea shrimp in the shell without a head, the process of convective drying can be characterized by the presence of three periods: heating, constant drying speed, falling drying speed. For figure 2 shows that the studied curves have a shape characteristic of colloidal capillary-porous bodies. When the liquid evaporates from the surface of capillary-porous bodies have a three way $[1,3]$ :

- surface evaporation - when the surface of the body is covered with a continuous layer of moisture, the mass transfer process is similar to evaporation from the free surface of the liquid. This is the period of conditionally constant drying speed;

- focal evaporation, in which the process of mass transfer occurs partially with a free wetted surface, and partially with a dried;

- when the liquid level in the capillaries coincides with the visible geometric surface of the body. In this case, the evaporation surface moves inside, into the depth of the material to form a layer, which is an additional resistance to the transfer of heat and matter from the product.

The influence of the temperature of the working medium of the convective dryer $(\varphi=80 \%)$ is seen from the comparison of curves $1,2,3$ figure 2 . At $T=80 \ldots 90^{\circ} \mathrm{C}$, the drying process of boiled purified sea shrimp is characterized by low intensity (curve 2,3), which is explained by the insufficient potential of thermal conductivity. The change in the humidity of the working medium of the drying plant $(\varphi=30 \%$ and $55 \%)$ leads to the formation of a crust on the surface of the crater, which reduces the intensity of the process (these data are presented in the article as a mathematical model). Therefore, the values of the influencing factors corresponding to the data of curve 1 (fig. 2) it should be considered rational (close to optimal) for the process of convection drying of the purified boiled the Influence of the temperature of the working medium of the convection drying plant ( $\varphi=80 \%$ ) is seen from the comparison of the curves $1,2,3$ figure 2 . At $T=80 \ldots 90^{\circ} \mathrm{C}$, the drying process of boiled purified sea shrimp is characterized by low intensity (curve 2,3 ), which is explained by the insufficient potential of thermal conductivity. The change in the humidity of the working medium of the drying plant ( $\varphi=30 \%$ and 55\%) leads to the formation of a crust on the surface of the crater, which reduces the intensity of the process (these data are presented in the article as a mathematical model). Therefore, the values of the influencing factors corresponding to the data of curve 1 (fig. 2) it should be considered rational (close to optimal) for the process of convection drying of purified boiled sea shrimp. 
For figure 4 similar dependences characterizing the drying process of boiled sea shrimp in the shell without the head are presented. Based on similar arguments, the most rational should be recognized as the drying process of the object with the parameters corresponding to the curve 1.

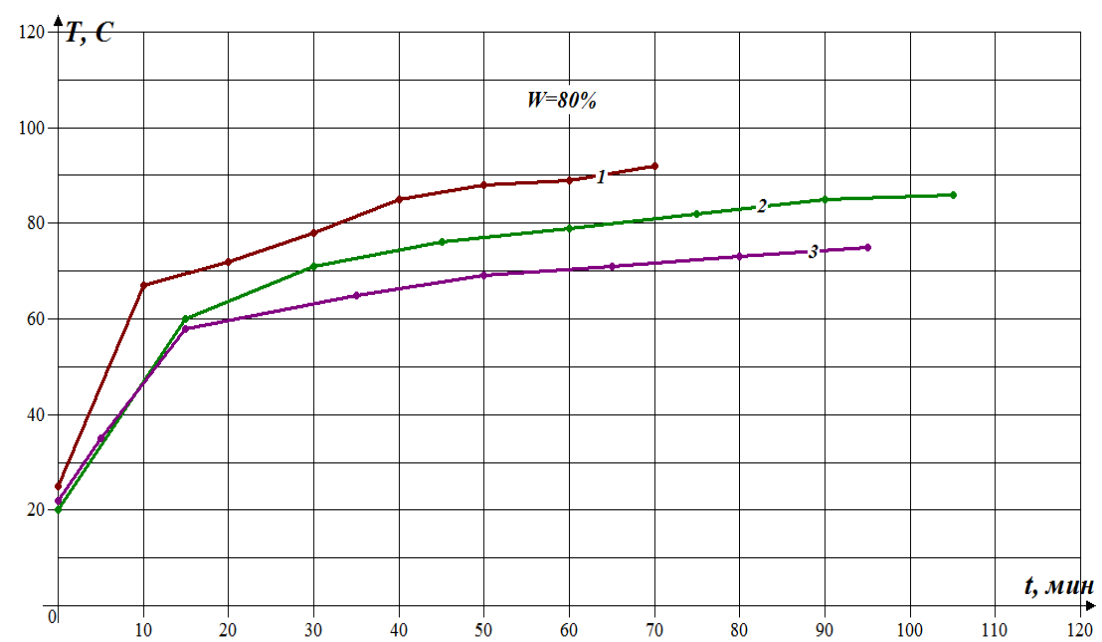

Figure 2. Thermograms $(1,2,3)$ of the purified boiled sea shrimp $(\varphi=80 \%)$ at various values of temperature of the working medium: $1-T=100^{\circ} \mathrm{C} ; 2-T=90^{\circ} \mathrm{C} ; 3-T=8 O^{\circ} \mathrm{C}$

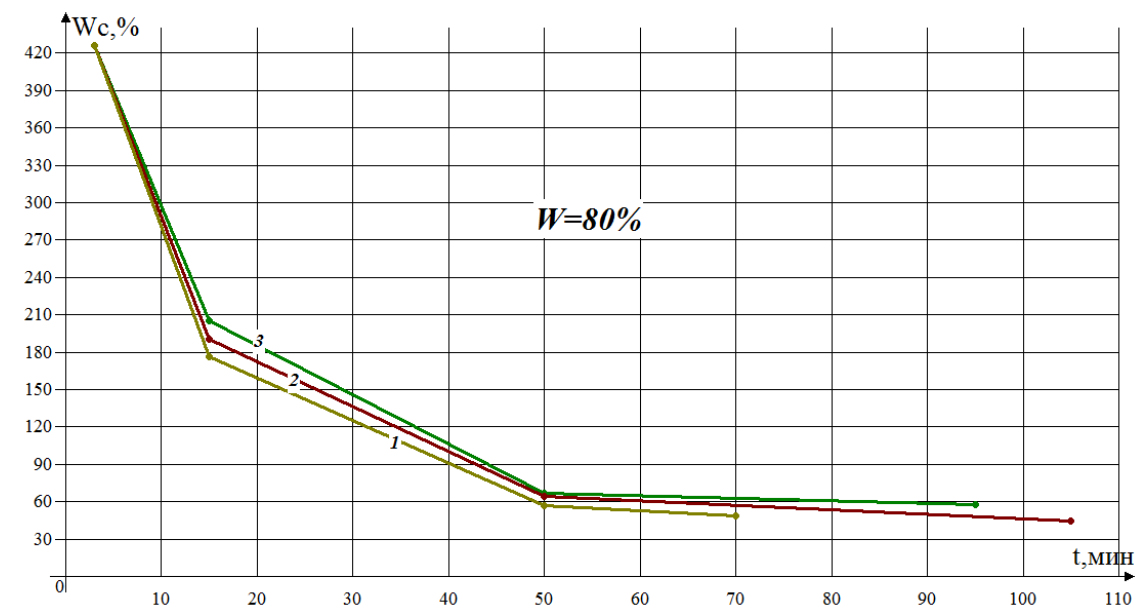

Figure 3. Drying curve $(1,2,3)$ of the purified boiled sea shrimp $(\varphi=80 \%)$ at different values of working medium temperature: $1^{\prime}-W S(\tau), T=100^{\circ} \mathrm{C} ; 2^{\prime}-W S(\tau), T=90^{\circ} \mathrm{C} ; 3^{\prime}-W S(\tau), T=80^{\circ} \mathrm{C}$

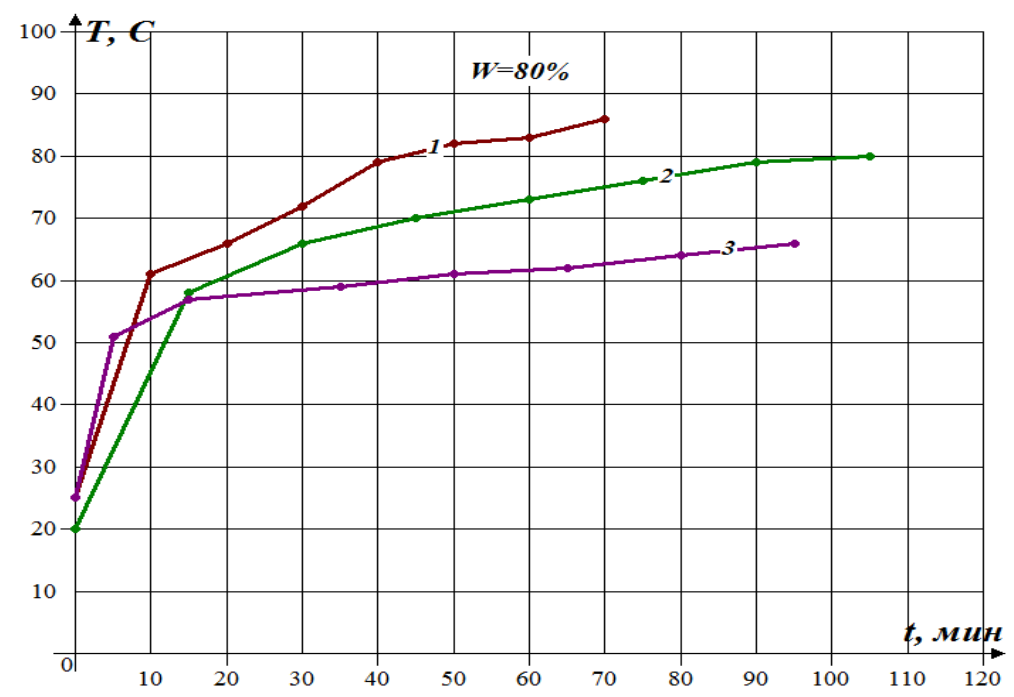

Figure 4. Thermograms $(1,2,3)$ of sea shrimp in a shell without head $(\varphi=80 \%))$ at different values of the working medium temperature: $1-T=100^{\circ} \mathrm{C} ; 2-T=90^{\circ} \mathrm{C} ; 3-T=80^{\circ} \mathrm{C}$ 


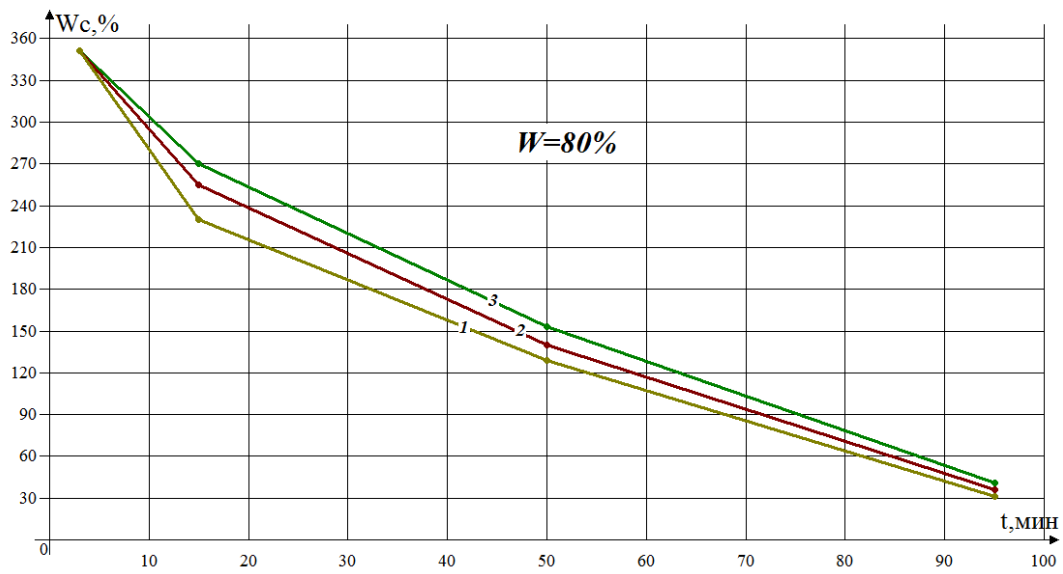

Figure 5. Drying curves (1', 2', 3') sea shrimp in a shell without head at different values of the working

For figure 3 shows the curves of drying of the meat of sea shrimp. The values of the current moisture news of material W $\mathrm{C}$ were calculated by the ratio of the moisture mass in the product to the mass of absolutely dry matter. Naturally, the drying curve of the purified sea shrimp 1 has the character of dependence, similar to the data in figure 3. It is just those races-judgements about what is happening the physics of the process of dehydration.

Curve 1 figure 6 characterizes the pattern of changes in the drying rate and more clearly displays the characteristic periods of dehydration of the material. The warm-up period, which is often excluded from the process analysis [1], corresponds to the right part of the curve 1 figure 6 . The period of constant rate of dehydration, for which there is no, since the product is formed crust prevents the removal of a large amount of moisture. The period of the falling rate of dehydration (left part fig. 6) has a form inherent in a homogeneous capillary-porous body $[1,3]$.

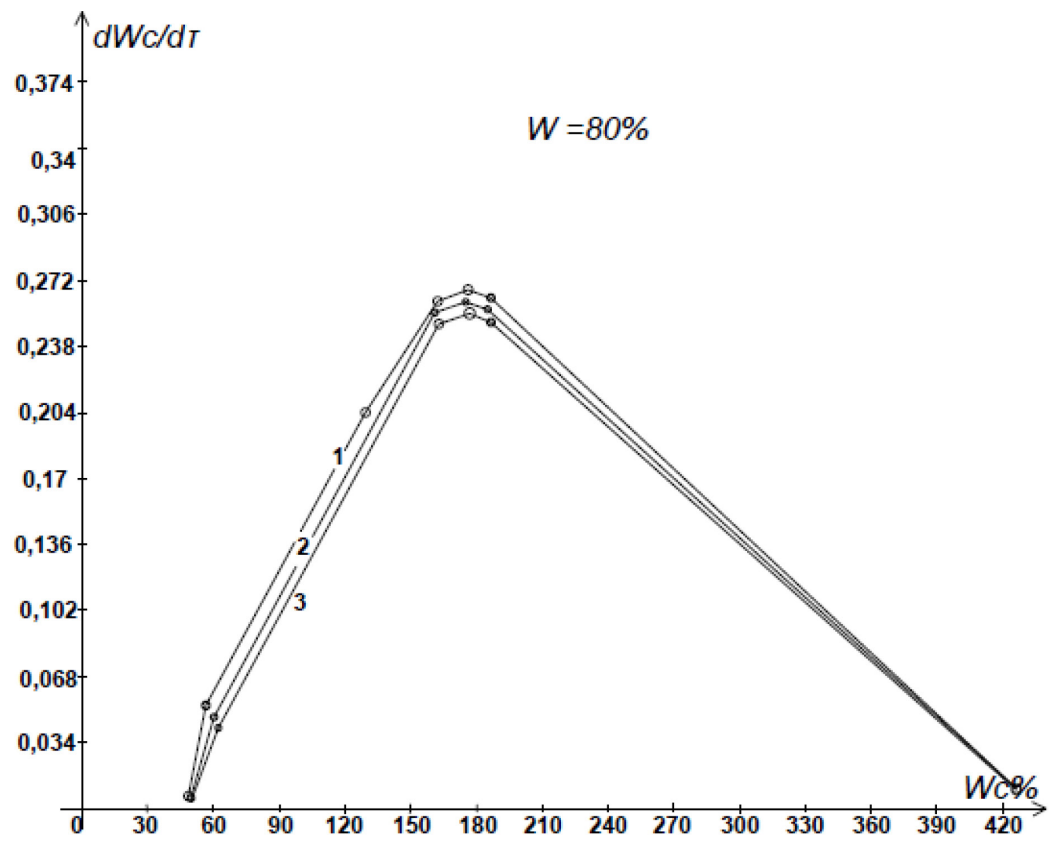

Figure 6. Curves of drying rate of treated cooked marine shrimp $\left(1-T=100^{\circ} \mathrm{C} ; 2-T=90^{\circ} \mathrm{C} ; 3-T=80^{\circ} \mathrm{C}\right)$

For figure 7 shows the drying curve of the sea shrimp in the shell without a head. A comparison of the data figure 6 and 7 show their qualitative coincidence, except for small differences in the nature of the curves corresponding to the period of the falling rate of dehydration. As noted above, this is probably due to the difference in these products in the process of dehydration of microcapillary osmotically bound moisture. Different speed of drying of objects of research (fig. 6,7 ) due to the difference in the test samples of the initial moisture content and type of cutting. 


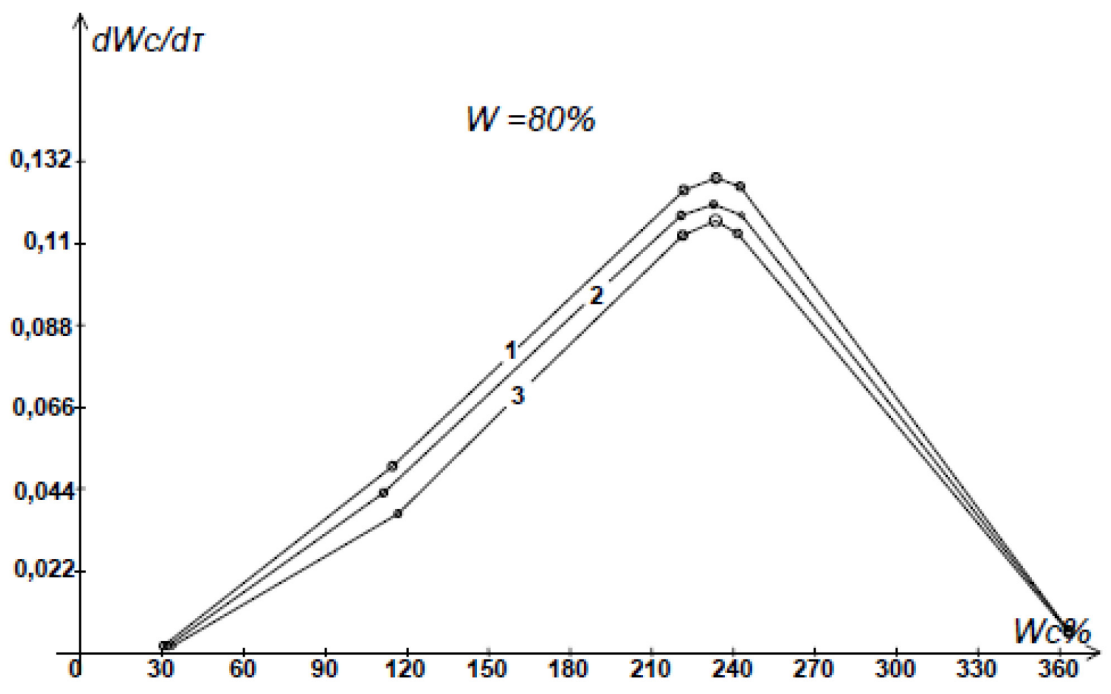

Figure 7. Drying rate curves of sea shrimp in a shell without head $\left(1-T=100^{\circ} \mathrm{C} ; 2-T=90^{\circ} \mathrm{C} ; 3-T=80^{\circ} \mathrm{C}\right)$

On curves of drying rate (fig. 6,7 ) it is seen that in the beginning of the warm-up period there is an intensive evaporation of moisture from the shrimp. Removes surface moisture and moisture of macro- and microcapillaries, transitional macropores. The speed of drying in this period is the maximum value $0.267 \% / \mathrm{min}$. for the meat of the shrimp and $0.127 \% / \mathrm{min}$. for shrimp in shell without heads. The period of constant drying speed is absent, because the crust is formed preventing the removal of moisture. The beginning of the period of falling drying speed corresponds to the critical moisture content of the material. At this time, the moisture is removed most firmly associated with the product. The intensity of evaporation decreases, the drying rate slows down, the temperature in the thickness of the product tends to a value equal to the temperature at the top. From figure 6, 7 it can be seen that the drying rate falls and at the end of the period has a minimum value. At the end of this period, the equilibrium moisture content of the shrimp is achieved, the drying process stops.

\section{Influence of regime parameters of drying}

In convective drying, the influencing factors of the process are the temperature $t$ and humidity $\varphi$ of the working medium of the drying plant.

As an optimization parameter, we choose the rate of dehydration of the product, which characterizes the rate of moisture removal during the process $[14,15]$ :

$$
V=\left(W_{0}^{c}-W_{e}^{c}\right) / \tau,
$$

where $W_{0}^{c} ; W_{e}^{c}$ - initial and final humidity of the product, referred to dry weight, \%;

$\tau$ - duration of drying, min.

At the same time, the task was to determine at what parameters of the process the minimum duration, i.e. the maximum performance of the installation for the finished product, will be provided. The limit was the final moisture content of the product and its quality.

When determining the type of the regression equation, we assumed that if the surface on which the desired point of the optimal ratio of the regime parameters of drying is curvilinear, then by varying factors it is possible to approximate this surface with a minimal error by a second-order polynomial [12, 13]:

$$
y=b_{0}+\sum_{1 \leq i \leq k} b_{i} x_{i}+\sum_{1 \leq i \leq k} b_{i 1} x_{i} x_{1}+\sum_{1 \leq i \leq k} b_{i i} x_{i}^{2},
$$

where $y$ - is a generalized optimization parameter;

$b_{0}, b_{i}, b_{i l}, b_{i i}$ - regression coefficients;

$x_{1}, x_{2}$ - coded values of factors.

In accordance with the known method of planning $[12,13]$, a complete factorial experiment of type $3^{2}$ was implemented. Levels and intervals of variation factors are presented in table 1. 
Table 1. Levels and intervals of variation by factors

\begin{tabular}{|c|c|c|c|c|c|}
\hline \multirow{2}{*}{ Factors } & \multirow{2}{*}{$\begin{array}{c}\text { Coded } \\
\text { table of symbols }\end{array}$} & Variation & \multicolumn{3}{|c|}{ Factor level } \\
\cline { 4 - 6 } & intervals & $\begin{array}{c}\text { Main } \\
0\end{array}$ & $\begin{array}{c}\text { Top } \\
+1\end{array}$ & $\begin{array}{c}\text { Lower } \\
-1\end{array}$ \\
\hline$T$ - fluid temperature, ${ }^{\circ} \mathrm{C}$ & $x_{1}$ & 10 & 90 & 100 & 80 \\
\hline $\begin{array}{c}\varphi-\text { the humidity of the } \\
\text { working environment, \% }\end{array}$ & $x_{2}$ & 25 & 55 & 80 & 30 \\
\hline
\end{tabular}

The planning matrix and experimental results are presented in table 2.

Table 2. The results of experiments on drying peeled shrimp and shrimp without a head

\begin{tabular}{|c|c|c|c|c|c|c|c|c|c|c|c|}
\hline \multirow{2}{*}{$\begin{array}{l}\text { № } \\
\Pi / \Pi\end{array}$} & \multirow{2}{*}{$x_{1}$} & \multirow{2}{*}{$x_{2}$} & \multirow{2}{*}{$x_{1} x_{2}$} & \multirow{2}{*}{$x_{1}^{2}$} & \multirow{2}{*}{$x_{2}{ }^{2}$} & \multicolumn{3}{|c|}{$\begin{array}{l}\text { Peeled shrimp, } \\
\mathrm{W}_{\mathrm{o}}^{\mathrm{c}}=426 \%\end{array}$} & \multicolumn{3}{|c|}{$\begin{array}{c}\text { Shrimp in the shell } \\
\text { without a head, } \mathrm{W}_{\mathrm{o}}^{\mathrm{c}}=351 \%\end{array}$} \\
\hline & & & & & & $W_{k}^{c}, \%$ & $\tau, \min$ & $y$ & $W_{k}^{c}, \%$ & $\tau, \min$ & $y$ \\
\hline 1 & -1 & -1 & +1 & +1 & +1 & 63.66 & 105 & 3.45 & 34.39 & 105 & 3.02 \\
\hline 2 & -1 & 0 & 0 & +1 & O & 79.13 & 105 & 3.30 & 53.25 & 105 & 2.83 \\
\hline 3 & -1 & +1 & -1 & +1 & +1 & 57.30 & 95 & 3.88 & 40.84 & 95 & 3.26 \\
\hline 4 & 0 & -1 & 0 & 0 & +1 & 105.17 & 60 & 5.34 & 54.09 & 60 & 4.94 \\
\hline 5 & 0 & 0 & 0 & 0 & 0 & 82.84 & 70 & 4.90 & 48.00 & 70 & 4.32 \\
\hline 6 & 0 & +1 & 0 & 0 & +1 & 44.53 & 105 & 3.63 & 34.40 & 105 & 3.02 \\
\hline 7 & +1 & -1 & -1 & +1 & $\mathrm{O}$ & $53 \cdot 31$ & 70 & 5.32 & 43.84 & 70 & 4.39 \\
\hline 8 & +1 & 0 & 0 & +1 & 0 & 49.25 & 70 & 5.38 & 40.00 & 70 & 4.44 \\
\hline 9 & +1 & +1 & +1 & +1 & +1 & 48.36 & 70 & 5.39 & 30.89 & 70 & 4.57 \\
\hline
\end{tabular}

Implementation of the experimental plan and processing of the data obtained by the computer program DataFit Ver. 9.0.59, allowed to obtain the following regression equations adequately describing the influence of factors on the rate of convective drying.

In the coded values of the factors:

For peeled shrimp

$$
y=4.64+0.91 x_{1}-0.201 x_{2}-0.09 x_{1} \cdot x_{2}-0.17 x_{1}^{2}-0.025 x_{2}^{2} .
$$

For shrimp in a shell without a head

$$
y=4.09+0.715 x_{1}-0.25 x_{2}-0.015_{1} \cdot x_{2}-0.341 x_{1}^{2}-0.003 x_{2}^{2} .
$$

In natural values of factors:

For peeled shrimp

$$
V=18.77+0.416 T+0.28 \varphi-0.00036 T \varphi-0.0017 T^{2}-4 \cdot 10^{-5} \varphi^{2}
$$

For shrimp in a shell without a head

$$
V=-29.74+0.689 T-0.005 \varphi-6 \cdot 10^{-5} T \varphi-0.0034 T^{2}+5 \cdot 10^{-6} \varphi^{2} .
$$

The regression equations obtained allow not only to predict the value of the response function for the given conditions for the implementation of the process of convective drying of the purified shrimp and shrimp in the shell without a head, but also provide information about the shape of the click surface, which are presented in figure 8 and 9. 


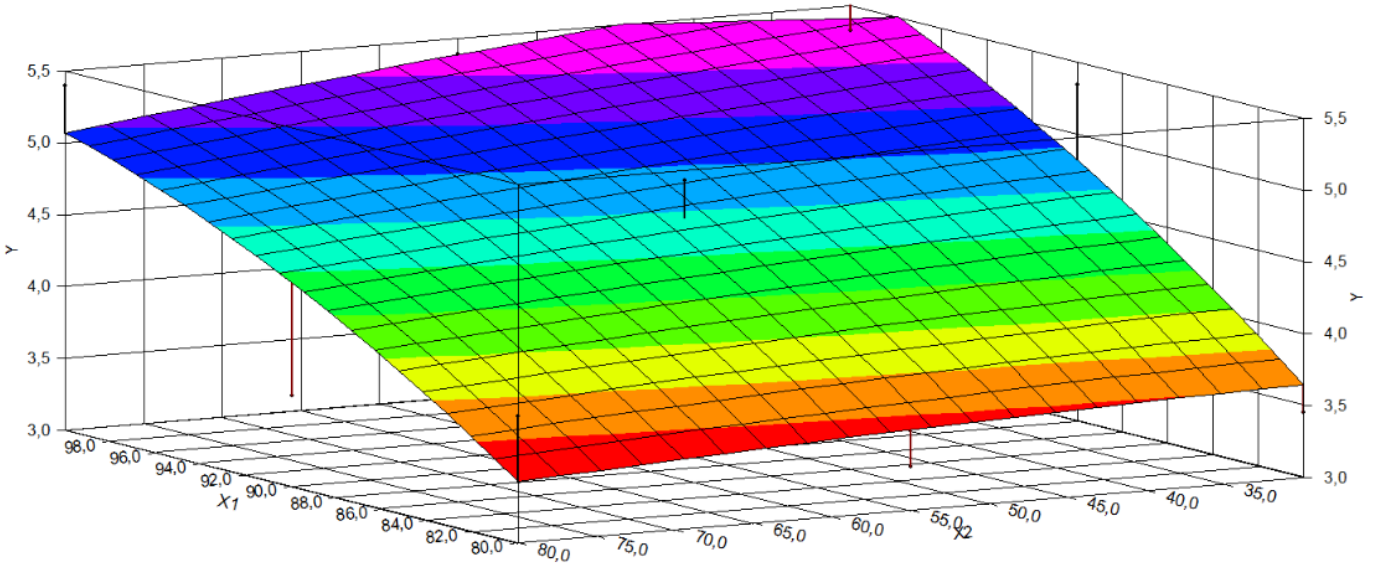

Figure 8. Surface response function y $\left(x_{1} ; x_{2}\right)$ in the selected area of the factor space for the purified shrimp

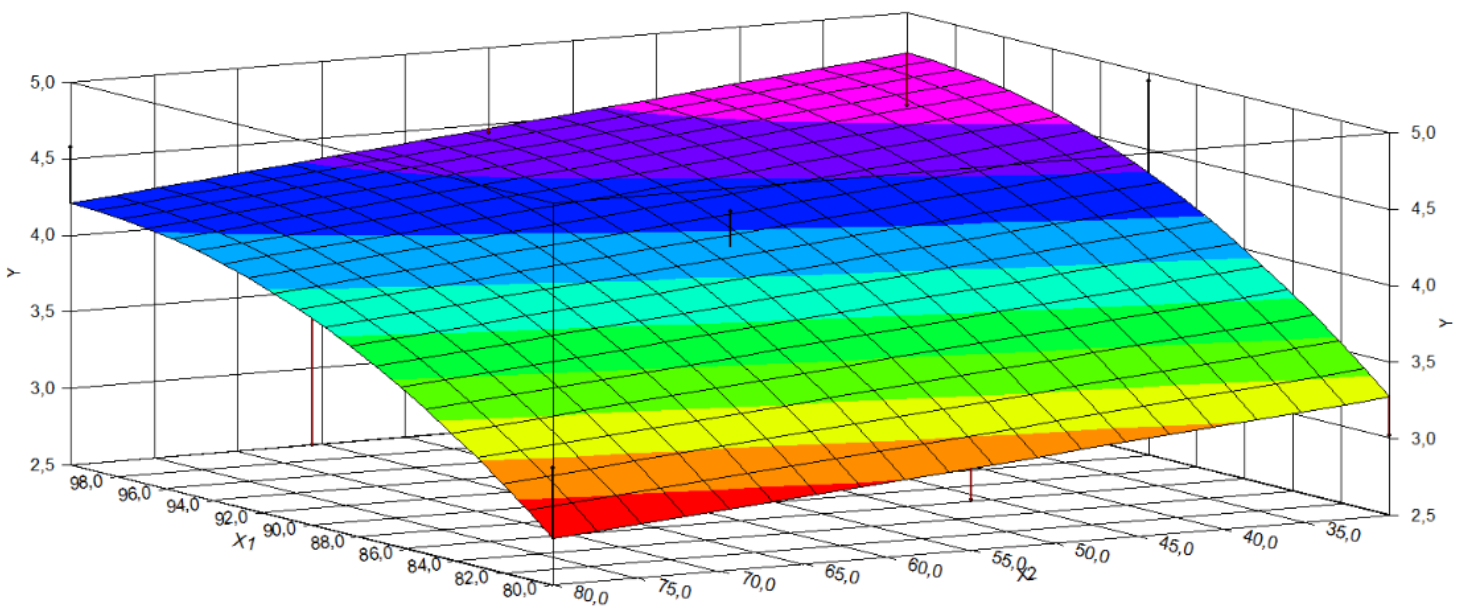

Figure 9. Surface response function $y\left(x_{1} ; x_{2}\right)$ in the selected area of the factor space for the headless shrimp in the shell

\section{Conclusion}

Experimental data on the kinetics of drying of purified sea shrimp and boiled sea shrimp in the shell without a head were obtained and processed. The method of carrying out experiments is proved. The method of obtaining meat of dried sea shrimp, which can be used in the preparation of snack products, is proposed and justified.

Kinetic regularities of convective drying of the purified boiled sea shrimp and boiled sea shrimp in the shell without the head were established at various parameters of the process: humidity of the working environment (air) $\varphi=30 . . .80 \%$, temperature $T=80 \ldots . .100^{\circ} \mathrm{C}$.

A mathematical model of the process of convective drying of boiled meat of sea shrimp and shrimp in the shell without the head, establishing the relationship of the process parameters: humidity $\varphi$ and temperature $T$ of the working medium of the convective drying unit at the rate of dehydration of the product.

The rational parameters of the process of convective drying of meat of sea shrimp and shrimp in the shell without a head $\varphi=80 \%, T=100^{\circ} \mathrm{C}$.

\section{References}

1. Ershov A.M. (ed.) Fish and fish products technology. Moscow, Kolos Publ., 2006. 941 p. (In Russian).

2. Semenov V., Kas'yanov G.I. Drying raw materials: meat, fish fruits, vegetables, milk. Rostov-on-Don, MarT Publ., 2002, 112 p. (In Russian).

3. Glazunov Yu.T., Ershov A.M., Ershov M.A., Pohol'chenko V.A. Processes of drying, smoking, calving of fish and their hardware decoration. Kaliningrad, Kaliningrad State Technical University Publ., 2013. 220 p. (In Russian).

4. Erlihman V.N., Fatykhov Yu.A., Suslov A.E. Energy saving in technological processes of agro-industrial complex using heat pump units. Kaliningrad. Kaliningrad State Technical University Publ., 2007. 236 p. (In Russian). 
5. Cai L., Nian L., Cao A., Li D. Effect of different drying methods on flavor components of Chinese shrimp (Fenneropnaeus Chinensis). Transactions of the Chinese Society of Agricultural Engineering. 2017, V. 33, no. 1, pp. 291-298.

6. Azizpour M., Monebbi M., Khodaparast MHH. Effects of foam-mat drying temperature an physico-chemical and microstructural properties of shrimp powder. Innovative Food and Emerging Technologies. 2016, V. 34, pp. 122-126.

7. Krasilnikov V.N., Alexeev G.V. Use of flaxseeds in the flour confectionery. International Food Research Journal. 2015, V. 22, no. 3, pp. 1156-1162.

8. Silva M.V.C., Rinheiro R.C., Silva L.H.M., Rodriges A.M.C. Determining the moisture transfer parameters during convective drying of Shrimp. Blucher Chemical Engineering Proceedings. 2015, V. 1, no. 2, pp. 5085-5092.

9. Ramachandran R.P., Akbarzaden M., Paliwal J. Compulational fluid dynamics in drying process modeling a technical review. Food and Bioprocess Technology. 2018, V. 11, Is. 2, pp. 271-292.

10. Antipov S.T., Panfilov V.A., Urakov O.A., Shahov S.V. System development of food technology. Moscow, KolosS. 2010, 762 p. (In Russian).

11. Glazunov Yu.T., Ershov A.M., Ershov M.A. Modeling food production processes. Moscow, KolosS Publ., 2008, 360 p. (In Russian).

12. Grachev Yu.P., Plaksin Yu.M. Mathematical methods for planning experiments. Moscow. DeLi-Print Publ., 2005. 296 p. (In Russian).

13. Alexeev G.V., Voronenko B.A., Lukin N.I. Mathematical methods in food engineering. St. Petersburg, Lan' Publ., 2012. 169 p. (In Russian).

14. Suslov A.E., Fatykhov Yu.A. Results of the study of the drying process of fish (roach and sabrefish. Processes and Food Production Equipment. 2012, no. 1. (In Russian).

15. Suslov A.E., Fatykhov Yu.A. The results of the study of the drying process of perch. Izvestya KGTU, 2011, no. 23, pp. 133-140 (In Russian). 